
original work is properly cited

\title{
Peran Badan Penyelesaian Sengketa Konsumen dalam Pengawasan Klausula Baku di Kota Palembang ${ }^{1}$
}

\author{
Sri Turatmiyah dan Arfianna Novera \\ Fakultas Hukum Universitas Sriwijaya \\ Jln. Palembang-Prabumulih Km 32 Inderalaya, Ogan Ilir Sumatera Selatan \\ efka_turatmiyah@yahoo.com;_arfiana_novera@yahoo.com
}

Naskah diterima: 8/7/2016; revisi: 26/10/2016; disetujui: 23/12/2016

\begin{abstract}
This research studies the role of BPSK (Badan Penyelesaian Sengketa Konsumen or Costumer's Conflict Resolution Board) in Palembang city in supervising the standard clause and any hindrances in that supervision. This research used the juridical-empirical research method supported by the regulatory approach and case approach. The result of the research showed that the role of BPSK in the supervision of inclusion of standard clause until recently is not applied well. This is due to BPSK simply waits for any complaints from customers and there is no any follow up from BPSK. Meanwhile, the hindrances in the supervision of standard clause are related to the absence of the regulation of implementation as amended in Article 52 letter (e) Law of Customer Protection. BPSK is not a judicial institution, and the operational cost of BPSK is burdened by local budget (APBD) coming from the customers, business actors and government that have a different culture.
\end{abstract}

Keywords: BPSK; standard clauses; contomers

\section{Abstrak}

Penelitian ini membahas peran Badan Penyelesaian Sengketa Konsumen (BPSK) Kota Palembang dalam mengawasi klausula baku dan hambatan-hambatan dalam pengawasan tersebut. Penelitian ini menggunakan metode penelitian yuridis empiris didukung pendekatan perundang-undangan dan pendekatan kasus. Hasil penelitian menunjukkan bahwa peran BPSK dalam pengawasan pencantuman klausula baku sampai saat ini belum terlaksana dengan baik. Hal ini dikarenakan BPSK hanya menunggu pengaduan dari konsumen dan tidak ada tindak lanjut dari BPSK. Sedangkan hambatan dalam pengawasan klausula baku adalah belum adanya aturan pelaksanaan sebagaimana diamanatkan dalam Pasal 52 huruf (e) UU Perlindungan Konsumen, BPSK bukan lembaga yudisial, dan biaya operasional BPSK dibebankan pada Anggaran Pendapatan Belanja Daerah serta keanggotaan BPSK yang berasal dari konsumen, pelaku usaha dan pemerintah dengan kultur yang berbeda.

Kata-kata Kunci: BPSK; klausula baku; konsumen.

1 Tulisan ini merupakan ringksan hasil penelitian Satek Universitas Sriwijaya dari Anggaran DIPA Unsri No. 042.01.2.400953/2016 tanggal 7 Desember 2015 sesuai dengan Surat Perjanjian Penugasan Pelaksanaan Penelitian Sains Teknologi dan Seni Unsri No. 591/UN9.3.1/LT/2016 tanggal 22 April 2016. 


\section{Pendahuluan}

Istilah "Klausula Baku"ternyata hampir tidak dikenal oleh sebagian besar konsumen khususnya di wilayah Kota Palembang. Hal ini dibuktikan dari hasil survey yang dilakukan di Kota Palembang hanya 2 dari 10 orang responden yang diwawancarai yang mengetahui istilah klausula baku. Setelah diberikan contoh bentuk dari klausula baku seperti “Barang yang sudah dibeli tidak dapat ditukar atau dikembalikan", klaim garansi tidak berlaku bagi baterai, charger dan cashing, serta pengelola parkir tidak bertanggung jawab jika terjadi kehilangan helm dan kendaraan", sebagian responden mengetahui hal tersebut. Pada dasarnya UUPK mengakui adanya klausula baku tersebut. Hal ini diatur dalam Pasal 18 UUPK yang menentukan bahwa: "Pelaku usaha dalam menawarkan barang dan atau jasa yang ditujukan untuk diperdagangkan dilarang membuat atau memcantumkan klausula baku pada setiap dokumen dan atau perjanjian apabila: a) menyatakan pengalihan tanggung jawab pelaku usaha; b) menyatakan bahwa pelaku usaha berhak menolak penyerahan kembali barang yang dibeli konsumen, c) menyatakan bahwa pelaku usaha berhak penyerahankembali uang yang dibayarkan atas barang dan atau jasa yang dibeli oleh konsumen; d) menyatakan pemberian kuasa dari konsumen kepada pelaku usaha baik secara langsung maupun tidak langsung untuk melakukan segala tindakan sepihak yang berkaitan dengan barang yang dibeli oleh konsumen secara angsuran, e)Mengatur perihal pembuktian atas hilangnya kegunaan barang atau pemanfaatn jasa yang dibeli oleh konsumen.

Ciri-ciri khas perjanjian baku yaitu: pertama, isinya ditetapkan secara sepihak oleh pihak yang lebih kuat. Dalam perjanjian ini kedudukan para pihak tidak seimbang, pihak pembuat perjanjian biasanya lebih kuat dalam hal ekonomi dan politik. Dalam perjanjian tersebut unsur mengenai adanya persesuaian kehendak diantara para pihak adalah fiktif. Karena perjanjian dibuat seakan-akan telah terjadi adanya kata sepakat secara bebas, yang sebenarnya tidak ada. Kedua, adanya klausula baku atau syarat-syarat eksonerasi. Syarat eksonerasi adalah syarat yang membatasi atau membebaskan tanggung jawab salah satu pihak dalam melaksanakan perjanjian. ${ }^{2}$

2 Dewi Hendrawati, "Penerapan Asas Kebebasan Berkontrak Dalam Pembuatan Perjanjian Baku (Studi Normatif Pada Perjanjian Pembiayaan Konsumen)", dalam Jurnal Masalah-Masalah Hukum, No. 4 Jilid 40 Tahun 2011, hlm. 415. 
Dipertegas lagi bahwa syarat eksonerasi ini mengikat para pihak yang membuatnya yaitu: pertama, By signature (penandatangan), jika seseorang yang menandatangani surat perjanjian adalah terikat oleh syarat-syarat yang ada meskipun ia tidak membacanya, dan tidak peduli apakah ia mengerti dan memahami isinya. Kedua, By Notice (pemberitahuan), jika syarat eksonerasi telah tercetak di atas surat yang diserahkan dari satu pihak kepada pihak lain atau diumumkan pada waktu perjanjian dibuat, maka syarat tersebut sudah masuk dalam perjanjian jika sudah ada pemberitahuan. ${ }^{3}$

Undang-Undang No. 8 Tahun 1999 tentang Perlindungan Konsumen (UUPK) mendefinisikan pengertian konsumen yaitu dalam Pasal 1 ayat (1) bahwa "setiap orang pemakai barang dan atau jasa yang tersedia dalam masyarakat baik bagi kepentingan diri sendiri, keluarga, orang lain maupun makhluk hidup lain dan tidak untuk diperdagangkan". Konsumen memperoleh barang dan atau jasa dengan cara "membeli" atau melalui "hadiah". Cara yang pertama membeli biasanya dibuat dalam bentuk perjanjian dengan pelaku usaha dan konsumen mendapat perlindungan hukum melalui perjanjian tersebut.

Berdasarkan ketentuan Pasal 1 angka 10 UU No. 8 Tahun 1999 tentang Perlindungan Konsumen (UUPK) disebutkan bahwa:" Klausula baku adalah setiap aturan atau ketentuan dan syarat-syarat yang telah dipersiapkan dan ditetapkan terlebih dahulu secara sepihak oleh pelaku usaha yang dituangkan dalam suatu dokumen dan atau perjanjian yang mengikat dan wajib dipenuhi oleh konsumen". Dalam UUPK diatur tentang larangan pencantuman klausula tertentu oleh pelaku usaha yang terdapat dalam Pasal 18, disertai dengan sanksi pidana yaitu pidana penjara dan pidana denda. Namun dalam kenyataannya klausula baku yang dilarang tersebut sampai sekarang masih dicantumkan oleh pelaku usaha tanpa adanya sanksi yang dikenakan. Hal tersebut dipengaruhi oleh sikap konsumen terhadap keberadaan klausula baku, ketaatan pelaku usaha terhadap aturan dan ketegasan aparatur negara dalam menegakan aturan dan sanksi.

Pelaku usaha dalam menggunakan klausula baku pada umumnya telah menyiapkan draft perjanjian untuk dipergunakan pada kegiatan usahanya yang 
pengaturannya sesuai dengan kegiatan usaha perusahaan tersebut, dalam bentuk perjanjian yang telah dibakukan. Pencantuman klausul baku dalam penawaran suatu produk barang dan atau jasa merupakan sesuatu yang diperbolehkan selama sesuai dengan ketentuan sebagaimana yang diatur dalam UUPK. Dengan pencantuman klausul baku tersebut akan memberikan sesuatu hal yang menguntungkan karena sifatnya lebih praktis dan efisien. Namun dalam praktik, pencantuman klausul baku seringkali memberatkan salah satu pihak dalam hal ini adalah konsumen yang meskipun demikian seringkali konsumen harus menerima kondisi tidak seimbang tersebut karena pada hakikatnya membutuhkan produk barang dan atau jasa tersebut.

Atas kerugian-kerugian yang mungkin ditanggung oleh konsumen sebagai akibat pencantuman suatu klausula baku, UUPK telah mengakomodasi dengan adanya ketentuan Pasal 49 ayat (1) yang menetapkan pembentukan Badan Penyelesaian Sengketa Konsumen (BPSK). Ditegaskan dalam Pasal 52 UUPK ini, tercantum tugas BPSK yaitu: memberikan konsultasi perlindungan konsumen, melakukan pengawasan terhadap pencantuman klausula baku, dan menerima pengaduan konsumen atas terjadinya pelanggaran perlindungan konsumen, serta tugas-tugas lainnya. Akan tetapi dalam praktiknya, masih banyak ditemukan kendala bagi konsumen dalam memperjuangkan hak-haknya menyangkut adanya kerugian-kerugian yang diakibatkan oleh pencantuman klausula baku dalam produk barang dan/atau jasa yang sudah dibelinya.

Pencantuman klausul baku yang sifatnya dilarang berdasarkan Pasal 18 ayat (1) UUPK masih banyak ditemukan dalam berbagai penawaran produk barang dan/atau jasa, sekalipun dijelaskan telah dibentuk BPSK sebagai sebuah badan yang mempunyai kewenangan melakukan pengawasan terhadap pencantuman klausul baku.Klausula baku dipergunakan oleh pelaku usaha antara lain dalam bisnis usaha perbankan, asuransi, jasa pegadaian, gas, listrik dan sebagainya baik perlaku usaha BUMN maupun swasta menggunakan perjanjian baku bagi konsumennya. Pelaku usaha menggunakan perjanjian baku dengan alasan karena bentuk perjanjian baku lebih praktis, mudah, cepat dan standar. Penggunaan perjanjian baku dapat meringankan pekerjaan para pelaku usaha. ${ }^{4}$

\footnotetext{
4 Zaelani, "Perjanjian Baku Berdasarkan Peraturan Perundang-Undangan Dalam Perspektif Perlindungan Konsumen”, dalam Jurnal Legislasi Indonesia No.4. Vol. 10, Tahun 2013, hlm. 402.
} 
Perjanjian baku mengabaikan asas-asas hukum perjanjian karena dibuat oleh satu pihak, sehingga cenderung kurang adanya keadilan bagi para pihak. Perjanjian baku lebih memberikan keuntungan bagi pelaku usaha saja, dengan cara menggunakan klausul eksonerasi sehingga konsumen yang menanggung kerugian. Kerugian-kerugian yang mungkin ditanggung oleh konsumen sebagai akibat pencantuman suatu klausul baku. Dalam rangka mengakomodasi penggunaan klausula baku tersebut telah ditentukan dalam Pasal 49 ayat (1) UUPK yang menetapkan pembentukan Badan Penyelesaian Sengketa Konsumen (BPSK). Kemudian dalam Pasal 52 UUPK ini, tercantum tugas BPSK yaitu: memberikan konsultasi perlindungan konsumen, melakukan pengawasan terhadap pencantuman klausul baku, dan menerima pengaduan konsumen atas terjadinya pelanggaran perlindungan konsumen, serta tugas-tugas lainnya.

Namun demikian, dalam praktiknya, masih banyak ditemukan kendala bagi konsumen dalam memperjuangkan hak-haknya menyangkut adanya kerugiankerugian yang diakibatkan oleh pencantuman klausul baku dalam produk barang dan/atau jasa yang sudah dibelinya. Pencantuman klausul baku yang sifatnya dilarang berdasarkan Pasal 18 ayat (1) UUPK masih banyak ditemukan dalam berbagai penawaran produk barang dan/atau jasa yang sudah pasti menimbulkan kerugian bagi konsumen.

\section{Rumusan Masalah}

Permasalahan dalam penelitian ini: pertama, bagaimana peran BPSK Kota Palembang dalam melakukan pengawasan terhadap klausula baku di Kota Palembang? Kedua, faktor-faktor apa yang menjadi hambatan BPSK dalam melakukan pengawasan klausula baku di Kota Palembang?

\section{Tujuan Penelitian}

Adapun tujuan penelitian ini adalah, pertama untuk menganalisis peran BPSK Kota Palembang dalam melakukan pengawasan terhadap klausula baku di Kota Palembang. Kedua, menganalisis faktor-faktor yang menjadi hambatan BPSK Kota Palembang dalam melakukan pengawasan klausula baku tersebut. 


\section{Metode Penelitian}

Penelitian ini merupakan penelitian hukum empiris dengan melakukan pengumpulan data primer melalui wawancara dengan sumber terkait. Yuridis empiris (yuridis sosiologis) yaitu suatu pendekatan yang dilakukan untuk menganalisa tentang sejauh manakah suatu peraturan atau perundang-undangan atau hukum yang sedang berlaku secara efektif. Penelitian ini menggunakan data yang diperoleh langsung dari masyarakat (mengenai perilaku nyata) dan dari bahan pustaka. Penelitian hukum empiris mengutamakan data sekunder untuk kemudian dilanjutkan dengan penelitian terhadap data primer di lapangan atau terhadap masyarakat. Hukum dipandang dari segi luarnya saja. Karena hukum dikaitkan dengan masalah sosial. Penelitian hukum empiris menitikberatkan perilaku individu atau masyarakat dalam kaitannya dengan hukum. Berdasarkan hal tersebut maka pendekatan yuridis empiris yaitu suatu pendekatan yang dilakukan untuk menganalisis tentang sejauh mana suatu peraturan atau perundang-undangan atau hukum berlaku secara efektif dalam masyarakat. ${ }^{5}$

Data primer diperoleh secara purposive sampling maksudnya adalah menentukan sampel dengan berbagai pertimbangan atau alasan. Teknik pengumpulan data dilakukan melalui wawancara terpimpin dengan beberapa orang responden diantaranya anggota BPSK unsur pemerintah, 1 orang unsur konsumen dan unsur pelaku usaha.Data diperoleh langsung dari lapangan dengan sumber yang relevan berkaitan dengan permasalahan penelitian.Kemudian data sekunder disebut dengan data kepustakaan yang mencakup antara lain: dokumendokumen resmi, buku-buku kepustakaan, hasil-hasil penelitian, yang berwujud laporan, dan sebagainya berupa bahan hukum primer, sekunder dan tersier. ${ }^{6}$

Metode pendekatan ini dilengkapi dengan: pertama, pendekatan perundangundangan (statute approach), yaitu pendekatan ini digunakan untuk memperoleh deskripsi analisis peraturan hukum yang mengatur tentang perlindungan konsumen. Kedua, pendekatan kasus (case approach), pendekatan ini digunakan untuk menelaah kasus-kasus mengenai sengketa konsumen yang masuk BPSK

\footnotetext{
5 Peter Mahmud Marzuki, Penelitian Hukum, Kencana, Jakarta, 2010, hlm. 87.

'Tbid., hlm. 141.
} 
Kota Palembang. Kemudian data yang terkumpul diolah dan dianalisis secara deskriptif kualitatif untuk mendapatkan suatu kesimpulan.

\section{Hasil Penelitian dan Pembahasan}

\section{Peran BPSK Kota Palembang Dalam Melakukan Pengawasan terhadap Klausula Baku}

Klausula baku memiliki banyak istilah lain dalam penyebutannya, diantaranya perjanjian baku (Bahasa Indonesia), Standart Contract (Bahasa Inggris). Tujuan dibuatnya klausula baku untuk memberikan kemudahan bagi para pihak yang bersangkutan. ${ }^{7}$

Bentuk perjanjian dengan klausula baku sangat menguntungkan jika dilihat dari berapa banyak, waktu, tenaga, dan biaya yang dapat dihemat. Akan tetapi di pihak lain bentuk perjanjian tersebut tentu saja menempatkan pihak yang tidak ikut membuat klausul-klausul dalam perjanjian baik langsung maupun tidak langsung sebagai pihak yang dirugikan. Dihal ini dikarenakan sebagai salah satu pihak dalam perjanjian yang memiliki hak untuk memperoleh kedudukan seimbang dalam menjalankan perjanjian tersebut, di sisi lain para pihak harus menurut terhadap isi perjanjian yang dimuat dalam klausula baku tersebut.

Kelemahan-kelemahan dalam perjanjian baku atau klausula baku bersumber dari karakteristik perjanjian baku dalam wujudnya merupakan suatu perjanjian yang dibuat oleh salah satu pihak yang menyisakan sedikit atau bahkan tidak sama sekali ruang bagi pihak lain untuk menegosiasikan isi perjanjian itu. Berlakunya perjanjian baku selain dari segi keabsahannya adalah adanya klausul-klausul yang tidak adil dan sangat memberatkan salah satu pihak. ${ }^{8}$

Pengawasan klausula baku dalam UUPK menjadi salah satu tugas dan wewenang dari BPSK sebagaimana disebutkan dalam Pasal 52 Huruf c. Walaupun pengawasan tersebut merupakan tugas dan wewenang BPSK akan tetapi masyarakat juga harus ikut melaksanakan pengawasan klausula baku dalam rangka penegakan hukum perlindungan konsumen.

${ }^{7}$ Munir Fuady, Hukum Kontrak (Dari Sudut Pandang Hukum Bisnis), Citra Aditya Bakti, Bandung, 2007, hlm.

${ }^{8}$ Celina Tri Siwi Kristiyanti, Hukum Perlindungan Konsumen, Sinar Grafika, Jakarta, 2009, hlm. 140. 
Di Kota Palembang masih ditemukan penggunaan klausula baku dalam perjanjian yang memuat klausula baku yang dilarang dalam UUPK. Klausula baku tersebut ditemukan baik pada pelaku usaha kecil, menengah, maupun besar. Hal ini terjadi karena semua pengusaha menerapkan perjanjian baku dengan klausula yang ditentukan pihak pengusaha saja. Karena itu sifat perjanjian baku dengan klausula baku "take it or leave it" dalam arti tidak memaksa pihak konsumen. 9 Misalnya penggunaan klausula baku tersebut oleh pelaku usaha kecil dan menengah sebagaimana telah disebutkan sebelumnya adalah klausula baku pada nota pembelian barang, nota penyediaan jasa seperti laundry, dan pada nota jasa parkir, jasa penitipan barang. Kemudian misalnya klausula baku yang digunakan oleh pelaku usaha besar adalah klausula baku pada perjanjian kredit, perjanjian leasing, perjanjian asuransi maupun lembaga perbankan dan lembaga pembiayaan.

Berdasarkan hasil wawancara dengan Yusrizal, Sekretariat BPSK Kota Palembang, ${ }^{10}$ penggunaan klausula baku yang memenuhi rumusan sebagai klausula baku yang dilarang dalam UUPK oleh pelaku usaha kecil dan menengah yang masih banyak mendominasi di Kota Palembang hal tersebut dikarenakan jumlah pelaku usaha yang sangat banyak sehingga kesulitan dalam pengawasan.

BPSK Kota Palembang dalam melakukan pengawasan klausula baku secara langsung di lapangan sebagai implementasi dari Pasal 52 huruf c UUPK belum dilaksanakan. Dijelaskan oleh Hardayani anggota BPSK dari unsur pemerintah, bahwa belum terlaksananya tugas pengawasan klausula baku karena BPSK Kota Palembang masih fokus pada penyelesaian sengketa konsumen. Kesulitan dalam tugas pengawasan klausula baku tersebut karena kultur dari anggota BPSK itu sendiri yang berasal dari unsur konsumen, unsur pelaku usaha dan unsur pemerintah para anggota dan majelis dari BPSK memiliki kesibukan masing-masing yang sulit untuk ditinggalkan.

Pengawasan klausula baku pada BPSK Kota Palembang dilakukan bersamaan dengan penyelesaian sengketa konsumen. Hal ini sebagaimana

\footnotetext{
9 Misalnya pengusaha kecil laundry yang mencantumkan klausula ("kerusakan/luntur karena pencucian diluar tanggung jawab pengusaha ), pengelola parkir (kehilangan helm, kendaraan diluar tanggung jawab pengelola), pengusaha menengah (ditemukan klausula baku "barang yang sudah dibeli tidak dapat ditukar atau dikembalikan) pengusaha besar di bidang lembaga leasing/keuangan/perbankan banyak ditemukan klausula baku“ jika debitur tidak membayar utang 2 kali berturut-turut benda objek jaminan ditarik oleh pihak leasing”).

10 Wawancara dilaksanakan pada tanggal 4 Agustus 2016 di BPSK Kota Palembang.
} 
disampaikan oleh Ramawan anggota BPSK Kota Palembang unsur konsumen, akhir-akhir ini banyak memediasi sengketa antara masyarakat dan perusahaan pengembang perumahan dan apartemen yang merasa ditipu oleh pengembang karena rumah dan apartemen yang disepakati dibangun hingga kini belum juga ada tanda-tanda dimulai pembangunannya. ${ }^{11}$ Salah satu kasus yang masuk ke BPSK Palembang seperti sengketa antara masyarakat dengan perusahaan yang akan membangun apartemen Basilica Palembang, yakni PT Trinitas Properti Persada.Sejumlah konsumen perusahaan tersebut meminta BPSK membantu mengembalikan uang muka dan cicilan di atas Rp100 juta yang telah diserahkan kepada pihak keuangan PT Trinitas Properti Persada.

Hal itu ditegaskan oleh Yusrizal selaku sekretariat BPSK Kota Palembang dalam proses penyelesaian sengketa konsumen tersebut di atas ${ }^{12}$, BPSK Kota Palembang berusaha meneliti perjanjian tersebut apakah merupakan klausula baku yang memenuhi rumusan sebagai klausula baku yang dilarang dalam UUPK atau bukan. ${ }^{13}$ Jika tergolong klausula baku yang dilarang dalam UUPK maka setelah sengketa berhasil diselesaikan BPSK melakukan pembinaan pelaku usaha bahwa klausula baku tersebut dilarang, kemudian secara berkala dilakukan pemeriksaan apakah perusahaan tersebut masih mencantumkan klausula baku yang dilarang tersebut atau tidak.

Pengawasan klausula baku yang dilaksanakan oleh BPSK hanya terbatas pada pengawasan setelah adanya sengketa, sedangkan untuk pengawasan klausula baku secara langsung terutama pada nota pembelian barang maupun jasa belum dilaksanakan sama sekali. Menurut Yusrizal belum dilaksanakannya pengawasan klausula baku secara langsung oleh BPSK Kota Palembang selain karena fokus pada penyelesaian sengketa konsumen juga dikarenakan belum adanya aturan teknis sebagai pelaksanaan Pasal 52 Huruf c UUPK, baik dari pemerintah pusat maupun pemerintah daerah Kota Palembang. Pelaksanaan

\footnotetext{
11 Wawancara dengan Anggota BPSK Kota Palembang dari unsur konsumen dilaksanakan pada tanggal 4 Agustus 2016 di BPSK Kota Palembang.

${ }^{12}$ Sampai bulan Agustus tahun 2016 kasus yang masuk ke BPSK Kota Palembang ada 37 kasus yang hampir sebagian besar adalah perjanjian baku $80 \%$ dapat diselesaikan secara damai, dan $20 \%$ menunggu proses penyelesaian sengketa.

13 Wawancara dilaksanakan pada tanggal 4 Agustus 2016 di BPSK Kota Palembang.
} 
pengawasan klausula baku tersebut di atas baru bersifat represif, karena baru dilakukan pengawasan klausula baku jika sudah terjadi sengketa. ${ }^{14}$ Namun pengawasan secara langsung di lapangan belum dilaksanakan secara penuh oleh BPSK Kota Palembang.

Fungsi utama perjanjian adalah untuk memberikan kepastian tentang mengikatnya suatu perjanjian antara para pihak. Fungsi tersebut dibedakan menjadi 2 (dua) yaitu: pertama, fungsi yuridis, yaitu untuk dapat memberikan kepastian hukum para pihak. Kedua, fungsi ekonomis, yaitu perjanjian untuk menggerakan hak milik sumber daya dari nilai penggunannya yang lebih rendah menjadi nilai yang lebih tinggi. ${ }^{15}$

Perjanjian mempunyai asas kebebasan berkontrak sebagaimana diatur dalam Pasal 1338 ayat (1) KUHPerdata bahwa "Semua perjanjian yang dibuat secara sah berlaku sebagai Undang-undang bagi mereka yang membuatnya. Hal ini berarti bahwa asas ini memberikan kebebasan kepada para pihak untuk: Pertama, membuat atau tidak membuat perjanjian. Kedua, kebebasan menentukan isi, syarat dan pelaksanaan perjanjian. Ketiga, kebebasan untuk menentukan bentuk perjanjian. Keempat, kebebasan untuk menentukan pilihan hukum.

Meskipun pelaku usaha mempunyai kebebasan membuat perjanjian yang berisi klausula baku, berdasarkan ketentuan Pasal 7 (a) UUPK bahwa:" Kewajiban pelaku usaha adalah "beritikad baik dalam melakukan kegiatan usahanya" itikad baik ini termasuk dalam etika bisnis yaitu nilai-nilai dan norma-norma moral yang berlaku bagi praktik bisnis. Etika bisnis menyangkut hati nurani pelaku usaha untuk membedakan antara apa yang baik dan apa yang buruk serta menetapkan nilai-nilai moral yang patut dikejar. Tujuan etika bisnis bukan mengubah keyakinan moral seseorang melainkan untuk meningkatkan keyakinan itu sehingga orang percaya pada diri sendiri dan akan memberlakukan di bidang bisnis. ${ }^{16}$ Berkaitan dengan klausula baku sudah tentu pelaku usaha harus menerapkan klausula-klausula yang tidak merugikan pihak konsumen.

\footnotetext{
14 Wawancara dilaksanakan pada tanggal 4 Agustus 2016 di BPSK Kota Palembang.

15 Lukman Santoso AZ, Hukum Perikatan Teori Hukum dan Teknis Pembuatan Kontrak Kerjasama Bisnis.,Penerbit Setara Press, Jakarta, 2016, hlm. 18.

${ }^{16}$ Bambang Eko Turisno, "Etika dalam Hubungannya Dengan Transformasi Global dan Hukum Kontrak Serta Perbuatan Melawan Hukum”, dalam Jurnal Masalab-Masalab Hukum, No. 3, Jilid 40 Tahun 2011, hlm. 292.
} 
Hambatan-Hambatan BPSK dalam Melakukan Pengawasan Terhadap Pencatuman Klausula Baku

Dalam rangka memberikan perlindungan kepada konsumen atas pencantuman klausula baku dalam perjanjian, telah diatur dalam Pasal 18 UUPK sebagaimana tersebut di atas. Hal ini dimaksudkan untuk melindungi konsumen dari pembuatan klausula baku yang semena-mena dari para pelaku usaha, sehingga setiap individu mempunyai kedudukan yang sama di dalam hukum untuk melaksanakan dan meneguhkan hak-haknya. Ketentuan Pasal 18 bersifat membatasi atau mengurangi prestasi yang harus dilakukan pelaku usaha dan mengurangi hak konsumen untuk melakukan penawaran terhadap barang atau jasa yang ditawarkan pelaku usaha.

Berkaitan dengan pengawasan klausula baku sebagaimana ketentuan Pasal 18 UUPK tersebut, maka pemerintah membentuk Badan Penyelesaian Sengketa Konsumen (BPSK) sebagaimana dalam Pasal 1 angka (11) UUPK bahwa "Badan Penyelesaian Sengketa Konsumen (BPSK) adalah badan yang bertugas menangani dan menyelesaikan sengketa antara pelaku usaha dan konsumen". Kemudian diatur lebih lanjut dalam Pasal 52 yang menentukan bahwa "Tugas dan wewenang BPSK meliputi: a) melaksanakan penanganan dan penyelesaian sengketa konsumen dengan cara mediasi, atau arbitrase atau konsiliasi, b) memberikan konsultasi perlindungan konsumen; c) melakukan pengawasan terhadap pencatuman klausula baku; dan seterusnya.

Perjanjian baku atau standard contract, merupakan perjanjian yang telah ditentukan dan dituangkan dalam bentuk formulir. Mengenai perjanjian baku berlaku adagium "take it or leave it contract." Jika setuju silakan diambil jika tidak maka tinggalkan saja, artinya perjanjian tersebut tidak dilakukan. Kondisi seperti ini menjadikan konsumen memiliki posisi tawar yang lemah. ${ }^{17}$ Berkaitan dengan hal tersebut, dalam ketentuan Pasal 9 Keputusan Menteri Perindustrian dan Perdagangan R.I. No. 350/MPP/Kep/12/2001 Tentang Pelaksanaan Tugas dan Wewenang BPSK diatur bahwa: 1) pengawasan terhadap pencantuman klausula

${ }^{17}$ Munir Fuady, Op. Cit., hlm. 76. 
baku, sebagaimana dimaksud dalam Pasal 3 huruf c, dilakukan oleh BPSK dengan atau tanpa pengaduan dari konsumen, 2) hasil pengawasan pencantuman klausula baku sebagaimana dimaksud dalam ayat (1) yang membuktikan adanya pelanggaran terhadap larangan pencantuman klausula baku di dalam Undangundang Perlindungan Konsumen, diberitahukan secara tertulis kepada pelaku usaha sebagai peringatan, 3) peringatan tertulis sebagaimana dimaksud dalam ayat (2) dilakukan 3 kali berturut-turut dengan tenggang waktu untuk masing-masing peringatan 1 (satu) bulan, 4) bilamana pelaku usaha tidak mengindahkan peringatan tertulis sebagaimana dimaksud dalam ayat (3), maka BPSK melaporkan kepada Penyidik Pegawai Negeri Sipil (PPNS) yang ruang lingkup tugas dan tanggung jawabnya di bidang Perlindungan Konsumen untuk dilakukan penyidikan dan proses penuntutan sesuai dengan ketentuan peraturan yang berlaku.

Adanya klausula baku menjadikan posisi konsumen di tempat yang lemah. Karena perjanjian baku yang memuat klausula baku sudah ditetapkan oleh pihak pelaku usaha. Kondisi konsumen yang dirugikan tentu memerlukan peningkatan upaya untuk melindunginya, hal ini dimaksudkan agat tercipta keseimbangan posisi antara konsumen dan pelaku usaha. Konsumen mempunyai hak-hak yang sempurna yang memenuhi 3 syarat, yaitu hak itu dibutuhkan untuk perkembangan manusia, hak itu diakui oleh masyarakat dan hak itu dinyatakan demikian dank arena itu dilindungi dan dijamin oleh lembaga negara. ${ }^{18}$

Keberadaan UUPK sebagai upaya hukum dimaksudkan untuk menjamin kepastian hukum ternyata belum cukup mampu memberikan perlindungan hukum kepada konsumen. Faktanya konsumen tetap saja dalam kedudukan dan posisi tawar yang lemah, seperti pelaku usaha membohongi konsumen melalui iklan, promosi yang dapat terjadi dalam bentuk pernyataan salah, pernyataan yang menyesatkan ataupun iklan yang berlebihan. Namun karena kedudukan pelaku usaha berada pada kedudukan yang lebih kuat, baik secara ekonomis, maupun segi kekuasaan dibandingkan dengan konsumen, sehingga konsumen sangat,

18 Sofian Parerungan, Tanggung Jawab Pelaku Usaha Terhadap Produk Cacat Menurut UU No 8 Tahun 1999 tentang Perlindungan Konsumen, artikel dalam Jurnal Varia Peradilan No. 340.,Tahun XXIX , Maret 2014, hlm. 74 . 
memerlukan bantuan advokasi, perlindungan serta upaya penyelesaian sengketa secara patut atas hak-hak konsumen. ${ }^{19}$

BPSK Kota Palembang adalah badan yang dibentuk melalui Keppres No. 90 Tahun 2001 di sepuluh kota di Indonesia, yaitu sebagai suatu lembaga yang berwenang untuk menyelesaikan sengketa konsumen di luar pengadilan. Sebagaimana diatur dalam Pasal 1 angka (11) UUPK bahwa "Badan Penyelesaian Sengketa Konsumen adalah badan yang bertugas menangani dan menyelesaikan sengketa antara pelaku usaha dan konsumen". Tujuan pembentukan BPSK adalah untuk melindungi konsumen maupun pelaku usaha dengan menciptakan sistem perlindungan konsumen yang mengandung unsur kepastian hukum dan keterbukaan informasi, termasuk dalam pengawasan klausula baku sebagaimana diatur dalam Pasal 52 huruf (c) UUPK.

UUPK tidak melarang pelaku usaha untuk membuat klausula baku atas setiap dokumen dan perjanjian transaksi usaha perdagangan barang atau jasa, selama dan sepanjang klausula baku tersebut tidak mencantumkan ketentuan sebagaimana dilarang dalam Pasal 18 ayat (1), serta tidak "berbentuk" sebagaimana dilarang dalam Pasal 18 ayat (2) UUPK tersebut". Tujuan penggunaan klausula baku dalam kegiatan bisnis sebenarnya untuk menghemat waktu dalam setiap kegiatan jual beli, amat tidak efisien apabila setiap transaksi antara pihak penjual dan pembelimembicarakan tentang isi kontrak jual beli tersebut.

Berdasarkan hasil wawancara dengan Yusrizal Sekretariat BPSK dari unsur pemerintah bahwa BPSK bersifat pasif dan hanya bertindak jika ada pengaduan atau keluhan dari konsumen. ${ }^{20}$ BPSK tidak mempunyai kewenangan menindaklanjuti terhadap pelaku usaha yang menerapkan klausula baku yang dilarang karena belum ada peraturan teknisnya yang mengatur cara melakukan pengawasan klausula baku tersebut.BPSK hanya meminta kepada pelaku usaha untuk menghapus klausula yang dilarang itu jika menimbulkan sengketa. Adapun klausula yang dilarang sebagaimana yang tercantum dalam Pasal 18 UUPK.

19 Holijah, "Pengintegrasian Urgensi dan Eksistensi Tanggung Jawab Mutlak Produk Barang Cacat Tersembunyi Pelaku Usaha Dalam UUPK di Era Globalisasi”, dalam Jurnal Dinamika Hukum, No. 1, Vol. 14 Tahun 2014, hlm. 177.

20 Wawancara dilaksanakan pada tanggal 5 Agustus 2016 di BPSK Kota Palembang. 
Berdasarkan data-data yang berhasil dikumpulkan melalui wawancara di Kantor BPSK Kota Palembang dengan Yusrizal sekretariat BPSK, Hardayani anggota dari unsur pemerintah, Arman Zainudin unsur pelaku usaha, dan Ramawan unsur konsumen, ${ }^{21}$ dapat diketahui, bahwa hambatan dalam melakukan pengawasan klausula baku di Kota Palembang berupa hambatan internal dan eksternal. Ditegaskan bahwa dalam rangka pelaksanaan tugas BPSK sebagai badan yang dibentuk untuk melindungi konsumen, khususnya dalam melakukan pengawasan terhadap klausula bakudiperlukan fasilitas, seperti sumber daya manusia yang memadai, sarana dan prasarana, serta keuangan yang cukup.

Berdasarkan hasil wawancara dengan pihak sekretariat BPSK Kota Palembang Yusrizal, bahwa pelaksanaan pengawasan terhadap klausula baku terdapat hambatan-hambatan baik secara internal maupun eksternal. Adapun hambatan internal antara lain: Pertama, belum terdapatnya aturan pelaksanaan terkait pengawasan klausula baku oleh BPSK Kota Palembang sebagai pelaksanaan dari aturan umum mengenai pengawasan klausula baku sebagaimana diamanatkan dalam Pasal 52 huruf (e) UUPK, Kedua, kurangnya sumber daya manusia sebagai struktur BPSK sehingga dalam pelaksanaan pengawasan pencantuman klausula baku sampai sekarang belum efektif, dan karena unsur anggota BPSK yang terdiri dari unsur pemerintah, unsur konsumen dan unsur pelaku usaha yang masing-masing mempunyai kesibukan dengan tugasnya masing-masing, Ketiga, pengawasan yang dilaksanakan sifatnya masih pembinaan sehingga apabila ditemukan pelanggaran terkait pencantuman klausula baku, tidak ada sanksi yang dijatuhkan, Keempat, BPSK lebih memilih pasif karena BPSK memiliki juga kewenangan sebagai lembaga penyelesaian sengketa konsumen di luar pengadilan, sehingga BPSK hanya menunggu laporan dari konsumen yang merasa dirugikan. ${ }^{22}$

Adapun hambatan eksternal adalah: Pertama, belum adanya kesadaran konsumen terhadap hak dan kewajibannya di bidang perlindungan konsumen

\footnotetext{
${ }^{21}$ Wawancara dilaksanakan pada tanggal 4 dan 5 Agustus 2016 di BPSK Kota Palembang.

22 Hasil wawancara dengan sekretariat BPSK Kota Palembang pengaduan yang masuk sampai bulan Agustus ada 37 kasus yang hampir sebagian besar adalah perjanjian baku, $80 \%$ dapat diselesaikan secara damai, dan $20 \%$ menunggu proses penyelesaian sengketa. Sebagian besar pengaduan dari konsumen berupa pengaduan perjanjian leasing, perjanjian property perumahan, perjanjian jual beli.
} 
sehingga jika mengalami kerugian akibat adanya klausula baku maka konsumen tidak tahu atau tidak mau melaporkan hal tersebut ke BPSK, jadi konsumen lebih banyak diam saja, Kedua, Konsumen kurang bahkan tidak mengetahui lembaga BPKS dan keberadaan, fungsi, dan tugas BPSK Kota Palembang sehingga mereka tidak tahu bagaimana cara memperoleh hak-haknya dalam perlindungan konsumen, Ketiga, Sifat pelaku usaha yang kurang peduli dan cenderung mengabaikan hak-hak konsumen, sehingga dalam pelaksanaan di bidang usahanya hanya ingin mendapatkan keuntungan yang besar tanpa memperhatikan hak-hak konsumen, Keempat, sangat sedikit sekali pengaduan yang masuk ke BPSK terkait kerugian akibat pencantuman klausula baku pada nota pembelian barang dan jasa sehingga BPSK berasumsi bahwa konsumen tidak mengalami kerugian terhadap nota pembelian barang dan jasa.

Hal yang sama ditegaskan Yusrizal, sekretariat BPSK Kota Palembang bahwa sebaiknya perlindungan konsumen menggambarkan perlindungan hukum yang diberikan kepada konsumen dalam usahanya untuk memenuhi kebutuhannya dari hal-hal yang merugikan konsumen itu sendiri. Hukum perlindungan konsumen saat ini cukup mendapat perhatian, karena menyangkut aturan-aturan guna mensejahterakan masyarakat. Sampai sekarang penegakan di bidang perlindungan konsumen masih relative rendah karena belum didukung sepenuhnya baik dari pemerintah maupun dari masyarakat itu sendiri yang belum ada kesadarannya untuk mengetahui dan menerapkan hak-haknya di bidang konsumen.

Namun dalam mencapai tujuan ini diperlukan pembaharuan hukum, institusi hukum dan profesi hukum yang mampu menjada integrasii dan persatuan nasional. Hukum perlindungan konsumen yang diharapkan adalah hukum perlindungan konsumen yang dapat digunakan sebagai mekanisme pengintegrasian yaitu melindungi kepentingan individu atau kelompok secara proporsional yaitu yang mendasarkan pada keadilan. ${ }^{23}$

Kemajuan di era globalisasi dan didukung kemajuan teknologi dan informasi telah memperluas ruang gerak arus transaksi barang dan jasa. Hal ini memberikan manfaat bagi konsumen karena kebutuhan akan barang dan jasa yang

${ }^{23}$ Holijah, Ibid., hlm. 178. 
diinginkan dapat terpenuhi serta semakin terbuka lebar kebebasan memilih aneka jenis dan kualitasnya. Di pihak lain konsumen menjadi objek aktivitas bisnis untuk meraup keuntungan yang sebesar-besarnya oleh pelaku usaha dengan cara apapun, termasuk dalam pencatuman klasula baku dalam perjanjian. ${ }^{24}$

Kewajiban konsumen diatur dalam Pasal 5 UUPK antara lain: a) membaca dan mengikuti petunjuk informasi dan prosedur pemakaian atau pemanfaatan barang dan atau jasa, demi keamanan dan keselamatan: b) beritikad baik dalam melakukan transaksi pembelian barang dan atau jasa; c) mengikuti upaya penyelesaian hukum sengketa perlindungan konsumen secara patut.

Berdasarkan hasil wawancara sebagaimana tersebut di atas, dalam UUPK yang diharapkan dapat menjadi senjata konsumen pencari keadilan dalam implementasinya ternyata masih sulit dilakukan. Demikian tugas BPSK dalam pengawasan klausula baku. Ketentuan diatas jelas menyebutkan bahwa BPSK dapat melakukan pengawasan terhadap klausula baku dengan atau tanpa pengaduan dari konsumen. Artinya BPSK dapat secara aktif melakukan pengawasan terhadap pencatuman klausula baku, tanpa pengaduan dari konsumen.

Hal yang sama ditegaskan oleh Yusrizal, ${ }^{25}$ selain hambatan-hambatan tersebut di atas dalam pelaksanaan di lapangan juga ditemukan kendala-kendala yang selalu dihadapi BPSK antara lain: Pertama, karena ketentuan hukumnya tidak sesuai sebagaimana diharapkan, yaitu untuk penyelesaian sengketa konsumen secara cepat, sederhana dan murah. Kedua, tidak adanya konsistensi pada pasalpasal dalam UUPK, adanya pertentangan antara pasal yang satu dengan pasal yang lainnya, maupun adanya konflik hosizontal produk perundang-undangan lainnya. Ketiga, kendala kelembagaan karena sampai saat ini lembaga BPSK keberadaannya masih terbatas, belum dibentuk pada setiap kabupaten sehingga menyulitkan bagi konsumen untuk menuntut hak-haknya. Keempat, kendala pendanaan karena biaya operasional tugas BPSK dibebankan pada APBD, namun ternyata pemerintah daerah kabupaten dan Kota tidak memasukan dana operasional BPSK ke dalam APBD. Kelima, kendala peraturan karena antara konsep

${ }^{24}$ H.Muchsin, Perlindungan Konsumen Terhadap Makanan dan Minuman Ditinjau Dari Aspek Kesehatan dan Hukum, dalam artikel Jurnal Varia Peradilan No. 287., Tahun XXV, Oktober 2009, hlm. 6

25 Wawancara dilaksanakan pada tanggal 5 Agustus 2016 di BPSK Kota Palembang. 
dan realita sering kali tidak sejalan. UUPK yang diharapkan dapat menjadi senjata bagi pencari keadilan, dalam implementasinya ternyata masih sulit dilakukan dan menghadapi berbagai kendala. Karena ketentuan hukumnya tidak sesuai sebagaimana diharapkan, yaitu untuk penyelesaian sengketa konsumen secara cepat, sederhana dan biaya murah.

\section{Penutup}

Berdasarkan pembahasan tersebut di atas, dapat disimpulkan bahwa peran BPSK Kota Palembang dalam menjalankan kewenangannya sebagaimana dalam Pasal 52 huruf (c) UUPK dalam pelaksanaan pengawasan belum dilaksanakan secara optimal karena bersifat pasif. Pengawasan dilakukan jika terjadi laporan atau pengaduan dari konsumen jika terjadi sengketa di lapangan. Pengawasan secara langsung terhadap penggunaan klausula baku baik pelaku usaha kecil, menengah maupun besar selama ini belum dilakukan. Hambatan-hambatan dan kendala yang dihadapi BPSK Kota Palembang dalam melaksanakan tugas dan kewenangan melakukan pengawasan terhadap penggunaan klausula baku adalah berupa hambatan internal dan eksternal. Hambatan internal antara lain: pertama, belum terdapatnya aturan pelaksanaan terkait pengawasan klausula baku oleh BPSK Kota Palembang sebagai pelaksanaan dari aturan umum mengenai pengawasan klausula baku sebagaimana diamanatkan dalam Pasal 52 huruf (e) UUPK, Kedua, kurangnya sumber daya manusia sebagai struktur BPSK sehingga dalam pelaksanaan pengawasan pencantuman klausula baku sampai sekarang belum efektif, dan karena unsur anggota BPSK yang terdiri dari unsur pemerintah, unsur konsumen dan unsur pelaku usaha yang masing-masing mempunyai kesibukan dengan tugasnya masing-masing, Ketiga, Pengawasan yang dilaksanakan sifatnya masih pembinaan sehingga apabila ditemukan pelanggaran terkait pencantuman klausula baku, tidak ada sanksi yang dijatuhkan, Keempat, BPSK lebih memilih pasif karena BPSK memiliki juga kewenangan sebagai lembaga penyelesaian sengketa konsumen di luar pengadilan, sehingga BPSK hanya menunggu laporan dari konsumen yang merasa dirugikan.

Hambatan eksternal adalah: pertama, belum adanya kesadaran konsumen terhadap hak dan kewajibannya di bidang perlindungan konsumen sehingga jika 
mengalami kerugian akibat adanya klausula baku maka konsumen tidak tahu atau tidak mau melaporkan hal tersebut ke BPSK, jadi konsumen lebih banyak diam saja, Kedua, Konsumen kurang bahkan tidak mengetahui lembaga BPKS dan keberadaan, fungsi, dan tugas BPSK Kota Palembang sehingga mereka tidak tahu bagaimana cara memperoleh hak-haknya dalam perlindungan konsumen, Ketiga, Sifat pelaku usaha yang kurang peduli dan cenderung mengabaikan hak-hak konsumen, sehingga dalam pelaksanaan di bidang usahanya hanya ingin mendapatkan keuntungan yang besar tanpa memperhatikan hak-hak konsumen, Keempat, sangat sedikit sekali pengaduan yang masuk ke BPSK terkait kerugian akibat pencantuman klausula baku pada nota pembelian barang dan jasa sehingga BPSK berasumsi bahwa konsumen tidak mengalami kerugian terhadap nota pembelian barang dan jasa. Adapun saran dari penelitian ini adalah UUPK seharusnya diterapkan lebih konsisten sehingga dapat memberikan perlindungan terhadap konsumen, yang sebagian besar mereka tidak memahami hak-haknya. Pemerintah perlu segera mengeluarkan peraturan sebagai pedoman BPSK dalam melaksanakan tugasnya melakukan pengawasan terhadap pencatuman klausula baku oleh pelaku usaha.

\section{Daftar Pustaka}

\section{Buku}

Fuady, Munir, Hukum Kontrak (Dari Sudut Pandang Hukum Bisnis), Citra Aditya Bakti, Bandung, 2003.

Mahmud Marzuki, Peter, Penelitian Hukum, Kencana, Jakarta, 2010.

Santoso AZ, Lukman, Hukum Perikatan Teori Hukum dan Teknis Pembuatan Kontrak Kerjasa dan Bisnis, Penerbit Setara Press, Jakarta, 2016.

Tri Siwi Kristiyanti, Celina, Hukum Perlindungan Konsumen, Sinar Grafika, Jakarta, 2009.

\section{Artikel Jurnal}

Eko Turisno, Bambang, "Etika Bisnis Dalam Hubungannya Dengan Transformasi Global Dan Hukum Kontrak Serta Perbuatan Melawan Hukum", dalam Jurnal Masalah-Masalah Hukum No. 3. Jilid 40 Tahun 2011.

Hendrawati, Dewi,“Penerapan Asas Kebebasan Berkontrak Dalam Pembuatan Perjanjian Baku (Studi Normatif pada Perjanjian Pembiayaan Konsumen)", artikel dalam Jurnal Masalah-Masalah Hukum, No. 4. Jilid 40 Tahun 2011. 
Holijah, "Pengintgrasian Urgensi dan Eksistensi Tanggung Jawab Mutlak Produk Barang Cacat Tersembunyi Pelaku Usaha Dalam UUPK di Era Globalisasi", dalam Jurnal Dinamika Hukum, No. 1. Vol. 14 Tahun 2014.

Muchsin, H, "Perlindungan Konsumen Terhadap Makanan dan Minuman Ditinjau Dari Aspek Kesehatan dan Hukum", dalamJurnal Varia Peradilan No. 287. Tahun XXV, Oktober 2009.

Parerungan, Sofian, “Tanggung Jawab Pelaku Usaha Terhadap Produk Cacat Menurut UU No 8 Tahun 1999 Tentang Perlindungan Konsumen", dalam Jurnal Varia Peradilan No. 340 Tahun XXIX Maret 2014.

Zaelani, "Perjanjian Baku Berdasarkan Peraturan Perundang-Undangan Dalam Perspektif Perlindungan Konsumen", artikel dalam Jurnal Legislasi Indonesia No. 4.Vol.10, Tahun 2013.

\section{Perundang-Undangan:}

\section{UUD NRI 1945}

Undang-Undang Nomor 8 Tahun 1999 tentang Perlindungan Konsumen (Lembaran Negara Republik Indonesia Tahun 1999 Nomor 42, Tambahan Lembaran Negara Republik Indonesia Nomor 3821).

Keputusan Presiden No. 90 Tahun 2001 tentang Pembentukan BPSK di 10 Kota di Indonesia.

Keputusan Menteri Perindustrian dan Perdagangan No. 350/MPP/Kep/12/2001 tentang Pelaksanaan Tugas dan Wewenang BPSK. 